\title{
Plasticity in growth, biomass allocation and root morphology in beech seedlings as induced by irradiance and herbaceous competition
}

\author{
Thomas CURT ${ }^{\mathrm{a}, \mathrm{b} *}$, Lluis COLL ${ }^{\mathrm{a}}$, Bernard PRÉVOSTO ${ }^{\mathrm{a}}$, Philippe BALANDIER ${ }^{\mathrm{a}}$, Georges KunstLeR ${ }^{\mathrm{a}}$ \\ ${ }^{a}$ Cemagref, Applied Ecology of Woodlands, BP 50085, 63172 Aubière, France \\ b Cemagref - UR Agriculture et Forêt Méditerranéennes, 3275 route Cézanne, BP 31 le Tholonet, 13612 Aix-en-Provence Cedex 1, France
}

(Received 16 October 2003; accepted 31 August 2004)

\begin{abstract}
Biomass increment, biomass allocation and fine-root morphology were compared on four-year old Fagus sylvatica seedlings growing under low (11\% relative irradiance), medium (14-19\%) or high (46\%) irradiance under natural Pinus sylvestris canopies, and under full light in a weeded meadow in the French Massif Central. Significant differences in biomass increment were found among plots in relation to light regime and interspecific competition. Light regime had little effect on shoot-to-root ratio and biomass allocation, but had a clear impact on above- and belowground morphological variables. Beech seedlings displayed a lower specific root length (SRL) and a higher specific leaf area (SLA) under shade, thus indicating morphological adjustment to shade. Similarly, competition from herbaceous vegetation had a negligible effect on seedling growth and biomass allocation, but significant impact on fine-root morphology. Low SLA and high SRL values at high irradiance coincided with high growth increments.
\end{abstract}

biomass allocation / European beech (Fagus sylvatica L.) / fine-root architecture / interspecific competition / irradiance

Résumé - Plasticité de la croissance de l'allocation de biomasse et de la morphologie racinaire chez les semis de hêtre provoquée par l'éclairement et la compétition herbacée. L'accroissement de biomasse, les patrons d'allocation de biomasse et la morphologie des racines fines ont été comparés sur des plants de hêtre (Fagus sylvatica L.) de quatre ans installés sous un boisement naturel de pin sylvestre à faible, moyen et fort éclairement $(11 \%, 14-19 \%$ et $46 \%$ d'irradiance relative), et en pleine lumière dans une prairie désherbée du Massif Central français. Les plants ont montré des différences significatives d'accroissement en biomasse selon l'éclairement relatif et l'intensité de la compétition avec le pin et les herbacées. L'éclairement a peu affecté le ratio biomasse aérienne / biomasse racinaire et l'allocation de biomasse au sein des différents compartiments, mais a eu un impact clair sur la morphologie foliaire et racinaire des plants. Les hêtres subissant un fort ombrage présentaient des racines fines peu ramifiées (faible longueur spécifique racinaire, SRL) et des feuilles peu épaisses (forte surface spécifique foliaire, SLA), ce qui suggère une faible capacité d'accès aux ressources du sol et un ajustement à une faible énergie lumineuse. De même, la végétation herbacée a eu un faible impact sur la croissance des hêtres et l'allocation de biomasse, mais a affecté significativement la morphologie de leur racines fines. Au total, des valeurs de SLA faibles et de SRL fortes à fort éclairement correspondent à de forts taux d'accroissement en biomasse.

allocation de biomasse / hêtre (Fagus sylvatica L.) / morphologie des racines fines / compétition interspécifique / éclairement sous forêt

\section{INTRODUCTION}

European beech (Fagus sylvatica L.) is a major late-successional species able to replace early-successional tree species in European temperate forests (e.g. [17, 49]). The "Chaîne des Puys" volcanic range of the French Massif Central presents a mosaic of wooded habitats (i.e., pioneer natural woodlands and shrublands) that may provide suitable habitats for beech. Field surveys indicate that beech seedlings establish sporadically under full-light conditions but mostly under the canopy of ageing Pinus or Betula pioneer woodlands $[16,32]$. They exhibit variable survival, growth, and morphology $[15,16]$ across the mosaic of habitats caused by woody colonization and pioneer stand dynamics. As a consequence, Fagus seedlings face variable irradiance levels and weed competition according to canopy closure. The literature has long established Fagus sylvatica as a shade-tolerant species [27] that appreciates shelterwood $[25,53]$. It is also considered as a rather drought-sensitive species, given clear evidence that belowground competition for water and nutrients from surrounding herbaceous vegetation severely limits seedling development under full-light conditions $[9,21,34]$.

Theory in plant ecology assumes that adaptive strategies allow subordinate late-successional and shade-tolerant species to establish under the canopy of shade-intolerant and pioneer species, in particular: (i) preferential biomass allocation to the

\footnotetext{
* Corresponding author: thomas.curt@ cemagref.fr
} 
most efficient organs for acquiring light [22, 26], water and nutrients [27]; and (ii) modification of the spatial arrangement and the efficiency of resource capture by these organs [20, 29]. The strategy to allocate biomass within plant could correspond to an optimisation process in response to stress [4]. But this issue is still debated as most studies indicated that changes in biomass allocation varied mostly with the age of trees, thus being mostly ontogenic $[24,49]$. Some authors hypothesize that shade entails preferential allocation to stems at the expense of roots and constant allocation to the foliage [42], while others indicate higher allocation to stem and leaves [46]. Morphological responses of aerial parts to competition from overstory and understory vegetation have been widely investigated for most temperate tree species. Converging evidence from the literature indicates that the shoots of Fagus seedlings display a large morphological and physiological acclimation capacity to light regime at crown-level $[33,39]$, branch-level $[11,26]$ as well as at leaf-level $[5,32,37,39]$. In particular, shading is expected to result in leaves with larger specific leaf area (SLA) [42]. High plasticity of leaf traits has been proved to coincide with high relative growth rates (RGR) [42]. Morphological plasticity in belowground parts has received much less attention although overstory species and grasses can outcompete beech $[8,10]$. However, studies are frequently unable to discriminate ontogenic effects of beech age from biotic (e.g. interspecific competition, browsing) and abiotic stresses (e.g. shade). Previous investigations in the 'Chaîne des Puys' indicated that fine-root morphology, root biomass and rooting profile of on naturally-regenerated beech saplings adapted to local crowding by the Pinus or Betula overstory $[15,16]$.

To investigate beech response to irradiance and competition from the surrounding vegetation, we studied biomass increment, biomass allocation, foliar and fine-root morphology over two seasons in two-year-old beech seedlings growing under experimental Pinus sylvestris stands, or in a weeded meadow. Seedlings had similar biomasses and age at the beginning of the experiment to prevent changes in biomass allocation patterns due to tree developmental stage [24]. Although in situ field experiments face problems in separating the specific effects of multiple growth variables on the target species, this approach was used to stay close to realistic interactions between beech seedlings and their competitors (e.g. studying real herbaceous communities and multiple interactions with the overstory instead of simulated shade). The aim of this study was to test the following hypotheses: (i) beech reacts strongly to competition from the over- and understory vegetation by modifying its morphology at leaf-level and fine-root level in order to improve its efficiency of light capture and soil resources absorption [3, 20, 26]; (ii) these changes correlate with biomass increment and allocation plasticity. To disentangle the impact of competition for light and soil resources, we assessed aboveground variables (relative irradiance, pine basal area, herbaceous biomass) and fine-root biomass and morphology of beech competitors (i.e., pine and herbaceous). More practical objectives were to assess the extent to which light and herbaceous interference affect beech development, and to gather information on the optimal growth conditions for this species within the study area.

\section{MATERIALS AND METHODS}

\subsection{Study sites and experimental design}

The study area was the volcanic range of the Chaîne des Puys (French Massif Central, longitude $2^{\circ} 59^{\prime} \mathrm{E}$, latitude $45^{\circ} 42^{\prime} \mathrm{N}$ ). The stands selected for the experiment presented a range of similar ecological features: elevation: 900 metres, physiographic position: plateau or moderate slope, and climate: mid-oceanic (mean annual rainfall $=$ $820 \mathrm{~mm}$; mean annual temperature $=7^{\circ} \mathrm{C}$ ). Soils are loamy Cambisols on basaltic tephras (FAO soil classification) with a typical mull or mull-moder humus. They display no major nutritional constraints since mean $\mathrm{pH}_{\text {water }}$ is 6.0 , mean $\mathrm{C}: \mathrm{N}$ ratio is 12 , and CEC is $33 \mathrm{mEq}$ per $100 \mathrm{~g}$ in the upper soil layer [15]. Native forest sites were mesic or gently acidic, with overstory dominated by Fagus sylvatica L., Abies alba Mill., and scattered Acer spp. or Prunus avium L.

The experimental design comprised five neighbouring stands located within a former agro-pastoral area typical of the "Chaîne des Puys" (Tab. I). Four forested stands were dominated by Scots pine, which established naturally after the cessation of grazing in the 1950s [41]. The last plot was a non-forested meadow, which was fully weeded with a glyphosate treatment, then manually harrowed during the whole experiment to maintain bare soil and to avoid any competition with herbs. Stands were selected to form a gradient of light regimes (= stand density) and stand ages comprising: (i) three young and dense Pinus-dominated stands at pole stage with a sparse understory, which were left intact or thinned to achieve three light regimes: low (LL, $11 \%$ relative irradiance), medium (ML $-\mathrm{V}, 19.2 \%$ relative irradiance) and high irradiance (HL, $46.5 \%$ relative irradiance); (ii) a submature Pinus-dominated stand of medium light regime (ML $+\mathrm{V}$, $16 \%$ relative irradiance) with an abundant understory vegetation; and (iii) a full-light regime (FL $-\mathrm{V}, 100 \%$ relative irradiance) control plot installed on a former meadow. This experimental design allowed not only comparisons within light gradients but also comparison between stands of medium light regime with very low vegetation competition $(\mathrm{ML}-\mathrm{V})$ and high vegetation interference $(\mathrm{ML}+\mathrm{V} ; \mathrm{Tab}$. I). Relative irradiance of 11 to $46 \%$ is within the range of light regimes that commonly occur in heterogeneous and sparse-canopied natural Scots pine woodlands in the study area [16].

All pine-dominated stands had similar mesic ground vegetation associating dicotyledons such as Galium or Fragaria spp. and graminae such as Festuca rubra and Dactylis glomerata with presumably high competitive ability $[9,10]$. To estimate the competition entailed by herbaceous species, we assessed aerial and fine-root $(<2 \mathrm{~mm})$ biomass on five replicates of $1 \mathrm{~m}^{2}$ on each stand. These plots were installed in areas that were representative of the stand. Shoot biomass was harvested while fine-root biomass was collected from a $70-\mathrm{cm}$ deep soil layer. In Pinus-dominated stands, the vegetation cover correlated positively with light regime: it was very sparse at dense pole stage whereas it developed considerably in thinned stands at high light regime and under the submature plot $\mathrm{ML}+\mathrm{V}$ (Tab. I). Data analysis (data not shown) indicated that herbaceous fine-root biomass increased exponentially with light in the dense pine stands $\left(R^{2} a d j=\right.$ $0.63)$, and was about 13-fold higher in the submature stand ( $M L+V)$ than in the young stand of similar relative irradiance ( $\mathrm{ML}-\mathrm{V})$.

On each stand we installed a fenced $18 \times 18 \mathrm{~m}$ square plot. Each plot included a $12 \times 12 \mathrm{~m}$ central zone surrounded by a 3-m buffer zone with similar stand characteristics. Central zones were subdivided into onehundred $1.2 \mathrm{~m}$ square units, with four units left apart and dedicated to seed sowing. On each plot, 96 two-year-old bare root seedlings (Fagus sylvatica $\mathrm{L}$.) purchased from a local nursery were randomly distributed and planted in November 2000 in the centre of each $1.2 \times 1.2 \mathrm{~m}$ unit. Randomisation and utilisation of two-year-old seedlings reduced possible ontogenic and size-dependent drifts in biomass [24]. An analysis of variance indicated that seedling biomass did not differ significantly among stands at the beginning of the experiment $(P>0.05)$. 
Table I. Main stand characteristics (mean \pm standard error).

\begin{tabular}{|c|c|c|c|c|c|}
\hline Stand & LL & $\mathrm{ML}-\mathrm{V}$ & HL & $\mathrm{ML}+\mathrm{V}$ & $\mathrm{FL}-\mathrm{V}$ \\
\hline Description & \multicolumn{3}{|c|}{ Young pine stand (pole stage) } & $\begin{array}{l}\text { Submature } \\
\text { pine stand }\end{array}$ & $\begin{array}{l}\text { Weeded } \\
\text { meadow }\end{array}$ \\
\hline Light regime & Low & Medium & High & Medium & Full light \\
\hline Herbaceous cover density & Low & Low & High & Medium & Null \\
\hline Mean overstorey density $\left(n \cdot h a^{-1}\right)$ & 4012 & 1451 & 496 & 1420 & \multirow{6}{*}{$\begin{array}{c}\text { Non } \\
\text { forested }\end{array}$} \\
\hline Mean overstorey basal area $\left(\mathrm{m}^{2} \cdot \mathrm{ha}^{-1}\right)$ & 52 & 31 & 15 & 49 & \\
\hline Mean overstorey age (yrs) & 25 & 25 & 25 & 40 & \\
\hline Pine fine-root biomass $\left(\mathrm{dw}, \mathrm{g} \cdot \mathrm{m}^{-2}\right) 0-30 \mathrm{~cm}$ & $3632 \pm 541 a$ & $3260 \pm 567 a$ & $2666 \pm 367 a$ & $2573 \pm 421 a$ & \\
\hline Pine root length increment (2001), m & $158 c$ & $117 b$ & $28 a$ & $2 a$ & \\
\hline Herbaceous aboveground biomass $\left(\mathrm{dw}, \mathrm{g} \cdot \mathrm{m}^{-2}\right)$ & $2 \pm 0.4 a$ & $7 \pm 2 a$ & $219 \pm 44 c$ & $48 \pm 13 b$ & \\
\hline Herbaceous fine-root biomass $\left(\mathrm{dw}, \mathrm{g} \cdot \mathrm{m}^{-2}\right) 0-30 \mathrm{~cm}$ & $7 \pm 0.4 a$ & $17 \pm 4 a$ & $143 \pm 32 b$ & $215 \pm 45 c$ & \multirow{2}{*}{ Weeded } \\
\hline Herbaceous root length increment (2001), m & $6 a$ & $69 a$ & $1141 b$ & $563 c$ & \\
\hline Relative irradiance $(\%)$ & $11.0 \pm 0.4 a$ & $19.2 \pm 0.7 c$ & $46.5 \pm 1.2 d$ & $16.0 \pm 0.6 b$ & 100.0 \\
\hline Near red-to-far-red ratio & 0.801 & 0.893 & 0.941 & 0.890 & 1.124 \\
\hline Soil water content $0-20 \mathrm{~cm}(\%) *$ & $11.2 \pm 0.2 a$ & $12.9 \pm 0.1 c$ & $12.3 \pm 0.1 b c$ & $12.5 \pm 0.1 b c$ & $12.9 \pm 0.4 c$ \\
\hline
\end{tabular}

LL: low irradiance; ML - V: medium irradiance and sparse herbaceous cover; HL: high irradiance; ML + V: medium irradiance and dense herbaceous cover; FL - V: full-light weeded. Different letters in a row indicate statistically significant differences (LSD procedure, $95 \%$ confidence interval).

* Soil water content was computed as the mean of weekly measurements over the 2002 growth season.

Mean global irradiance under the Scots pine canopy was measured with 16 TSL tube-solarimeters (1-m long, Delta-T ${ }^{\mathrm{TM}}$ device) distributed evenly over each plot at $0.7 \mathrm{~m}$ above ground. Each solarimeter was located at the centre of four seedlings. Measurements were integrated over $24 \mathrm{~h}$ in June 2001, and expressed as relative values of incident radiation measured at the same time under full-light conditions at the vicinity of each stand in the weeded meadow. The near red-tofar-red ratio was assessed with a Skye ${ }^{\mathrm{TM}} 110$ bi-band $(660-730 \mathrm{~nm})$ sensor (Skye Instruments, UK). Measurements were operated during $24 \mathrm{~h}$, simultaneously above and below the pine canopy. Changes in light quality varied little among stands (Tab. I) and it is unlikely that they would have a strong impact on beech growth [2]. Soil-water content was monitored weekly in the $0-20 \mathrm{~cm}$ soil layer with a TDR probe (Trime T3, IMKO ${ }^{\mathrm{TM}}$, Ettlingen, Germany) beside four beech seedlings per plot (see $[8,9])$.

\subsection{Growth, biomass allocation and root architecture of beech seedlings}

All beech seedlings were monitored throughout two growing seasons $(2001,2002)$ to assess shoot growth. We measured stem height, base diameter, and crown dimensions. Relative growth increments were computed at individual-scale in reference to the initial values at planting date. Biomass increment was computed for each seedling using allometric equations on a random subset of 33 seedlings before plantation. Correlations between initial shoot- and root- biomass, stem height, and base diameter were very high $\left(R^{2}\right.$ ranging from 0.95 to 0.99 ). In average, dry biomass before plantation was $0.59,0.35,6.16$, $5.79,1.91$ and $2.17 \mathrm{~g}$ for fine roots, main roots, taproot, stem, branches and leaves, respectively. Total dry biomass was $9.87 \mathrm{~g}$ (shoot), $7.10 \mathrm{~g}$ (roots) and $16.97 \mathrm{~g}$ (total), thus giving a unbalanced shoot-root ratio $($ mean $=1.39)$.

Specific leaf area (SLA, $\mathrm{cm}^{2} \cdot \mathrm{g}^{-1}$ ) was assessed following a standardized protocol after rehydratation [23]. A total of ten leaves were selected in the upper, median and lower part of each seedling. Leaf blades were cool-stored in airtight bags until processing. Each leaf was dried with tissue paper to remove any surface water, and immediately weighed to determine saturated fresh mass. The area of the fresh blade was determined using WinFolia ${ }^{\mathrm{TM}}$ software (Regent Instruments, Quebec, 2000), and dry mass was measured after oven-drying for five days at $70{ }^{\circ} \mathrm{C}$.

We randomly harvested six seedlings at the end of the first growth season (November 2001) and ten at the end of the second one (November 2002). Seedlings were harvested taking care to prevent root breaking [16], then cool-stored before treatment. They were divided into six compartments: leaves, branches, stems, taproots, coarse-roots (diameter $>2 \mathrm{~mm}$ ) and fine roots (diameter $<2 \mathrm{~mm}$ ), then weighed after oven-drying $\left(70{ }^{\circ} \mathrm{C}\right)$ for five days. Biomass allocation to each compartment was computed in g per compartment per $\mathrm{g}$ of total plant biomass (see [42]; Tab. IV). Since relative biomass in plant compartments is sensitive to whole plant biomass, this allometric approach allowed separating changes resulting from plant size from changes due to real shifts in partitioning [35]. To test the possible effect of plant mass we computed multiple ANOVA analysis (MANOVA) using seedling mass as a co-variable.

Fine-root morphology was assessed on three intact sub-samples per seedling. Samples corresponded to first- to third-order roots [20] to prevent morphological variations according to the position and the branching order $[3,40,50]$. Specific root length, mean fine-root diameter $(\mathrm{mm})$ and internode length $(\mathrm{mm})$ were assessed with the WinRhizo $^{\mathrm{TM}}$ image analysis software V 5.0A (Regent Instruments, 2000) since these variables were proved efficient for characterizing the soil exploitation strategy of forest tree species $[3,15,16,19]$.

\subsection{Assessment of competition above- and belowground}

Competition belowground was assessed by estimating the fine-root biomass and morphology of competitor plants (i.e. Pinus sylvestris and herbaceous species). Four root cores were extracted at a distance of 
Table II. Growth of Fagus seedlings two years after plantation (mean \pm standard error). Biomass increments were computed over two growth seasons (2000-2002) for the shoot, roots and the whole seedling. Stem diameter increment was computed over two growth seasons (20002002). At time of plantation (2000) the mean seedling biomass was $9.87 \mathrm{~g}$ (shoot), $7.10 \mathrm{~g}$ (roots) and $16.97 \mathrm{~g}$ (total) for a random subset of 33 seedlings. Different letters in a row indicate statistically significant differences (LSD procedure, 95\% confidence interval).

\begin{tabular}{|c|c|c|c|c|c|c|}
\hline Variable & LL & $\mathrm{ML}-\mathrm{V}$ & $\mathrm{ML}+\mathrm{V}$ & $\mathrm{HL}$ & $F L-V$ & $F$-Ratio \\
\hline Shoot biomass (dw, g) & $14.4 \pm 1 a$ & $28.7 \pm 4 a b$ & $24.6 \pm 2 a b$ & $38.0 \pm 3 b$ & $44.5 \pm 9 c$ & $6.42^{* * *}$ \\
\hline Root biomass (dw, g) & $14.2 \pm 1 a$ & $22.8 \pm 3 a b$ & $19.8 \pm 1 a b$ & $33.4 \pm 3 b$ & $40.1 \pm 6 c$ & $9.02^{* * * *}$ \\
\hline Total plant biomass ( $\mathrm{dw}, \mathrm{g}$ ) & $28.6 \pm 2 a$ & $51.5 \pm 7 a b$ & $44.4 \pm 3 a b$ & $71.4 \pm 6 b c$ & $84.6 \pm 14 c$ & $8.35^{* * *}$ \\
\hline Shoot biomass increment 2000-2002 (\%) & $70 \pm 14 a$ & $189 \pm 24 a b$ & $159 \pm 23 a b$ & $247 \pm 30 b$ & $507 \pm 126 c$ & $7.58^{* * * *}$ \\
\hline Root biomass increment 2000-2002 (\%) & $120 \pm 13 a$ & $222 \pm 26 a b$ & $192 \pm 25 a b$ & $337 \pm 41 b$ & $590 \pm 111 c$ & $10.88^{* * *}$ \\
\hline Total biomass increment 2000-2002 (\%) & $91 \pm 13 a$ & $203 \pm 23 a b$ & $173 \pm 23 a b$ & $284 \pm 31 b c$ & $540 \pm 113 c$ & $8.35^{* * *}$ \\
\hline Stem diameter increment 2000-2002 (\%) & $20.4 \pm 6 a$ & $34.3 \pm 11 b$ & $31.7 \pm 11 b$ & $47.2 \pm 12 c$ & $56.3 \pm 25 d$ & $18.24^{* * *}$ \\
\hline
\end{tabular}

${ }^{* * *} P<0.001 ;{ }^{* *} P<0.01 ;{ }^{*} P<0.05 ;$ NS: non significant $(P>0.05)$.

LL: low irradiance; ML - V: medium irradiance and sparse herbaceous cover; HL: high irradiance; ML + V: medium irradiance and dense herbaceous cover; FL - V: full-light weeded.

$40 \mathrm{~cm}$ around each target seedling (i.e., harvested) with a $7 \times 15 \mathrm{~cm}$ root corer, in the $0-15 \mathrm{~cm}$ and $15-30 \mathrm{~cm}$ soil layers. Roots were extracted from the mineral and organic soil using a 4-mm mesh sieve, and sorted according to their diameter (fine roots $<2 \mathrm{~mm}$, other roots $>2 \mathrm{~mm}$ ) and to the species (Scots pine versus herbaceous species). Root identification used morphological criteria such as colour, branching and flexibility. We used databases from the literature, our own reference materials and dichotomic keys [16]. Morphological measurements were performed using WinRhizo ${ }^{\mathrm{TM}}$ on pine and herbaceous fine-root subsamples as on beech. Root elongation over the active vegetation period was monitored for all species (beech, pine, weeds) on a pair of $1 \times 0.8 \mathrm{~m}$ rhizotrons per plot. Root drawings on transparent sheets were scanned and analysed using WinRhizo ${ }^{\mathrm{TM}}[8]$.

Competition aboveground by pine was assessed using the relative irradiance and a competition index. As Pinus-dominated natural woodlands were spatially heterogeneous, each seedling experienced a specific degree of competition from the pine overstory, depending on pine number, size and distance. Aboveground competition by pines was assessed by measuring the distance, the diameter at breast height (dbh) and the height of all surrounding pines within a $3 \mathrm{~m}$ competition radius around each seedling. We selected the Vast 3 distance-dependent competition index that has been proven efficient to predict the root development of naturally-regenerated beech saplings $[15,16]$. This index is computed as the sum of vertical angles from the top of each target tree (= beech seedling) to the top of each surrounding pine within the competition radius. Aboveground competition by the herbaceous layer was estimated by harvesting the aerial herbaceous biomass of each $1.20 \times 1.20 \mathrm{~m}$ square plot after extraction of seedlings. Dry biomass was weighed $( \pm 0.1 \mathrm{~g})$ after five days of drying in an oven $\left(70^{\circ} \mathrm{C}\right)$.

\subsection{Data analysis}

In this experimental design, individuals (i.e., Fagus seedlings) were considered as the experimental units since the various thinning treatments were not replicated. The effect of microhabitats on beech growth was tested with a general linear model (GLM). Variation of microhabitat was investigated within each stand. For each $1.2 \mathrm{~m}$ unit, we assessed the mean soil depth (three replicates using a soil auger), micro-topography, and soil covering by humus layer, mosses and bare soil. Microhabitats had no statistically significant effect on beech biomass increment over two years, except for the covering by humus layer $(P=0.0380)$ that mostly reflects light availability and canopy closure. As changes of microhabitat were of minor importance, radiation transmittance was assumed as the main source of variation of beech growth, and vegetation competition was computed as a co-variable. Seedling growth and morphology were also compared between the different treatments.

Responses of beech seedlings to ecological variables were assessed using simple and multiple linear regression analyses (i.e. nested variables) at individual and at stand scale, and analysis of variance (ANOVA) at stand scale. We used the natural data or log-transformed data when necessary in order to meet conditions of normality. The Fisher's LSD-procedure and multiple range tests were used to compare means between the stands. Probability values of $P<0.05$ were considered significant.

\section{RESULTS}

\subsection{Beech growth and stand competition}

Stand-scale comparisons revealed clear differences in beech growth two years after plantation (Tab. II). Aboveground, belowground, and total biomass of beech seedlings increased with irradiance, from deep shade to full light. The mean seedling biomass at full light was three-fold greater than that measured at low light (LL). Both stands of medium light regime showed similar biomass increment, although one had an abundant herbaceous cover $(\mathrm{ML}+\mathrm{V})$ whereas the other had sparse cover $(\mathrm{ML}-\mathrm{V})$. Beech had a high growth at high light (HL) despite the presence of an abundant herbaceous cover. The fulllight weeded plot $(\mathrm{FL}-\mathrm{V})$ showed the highest overall biomass increment but severe intra-plot variability. Relative biomass increments were higher for roots than for shoots in a same stand (Tab. II).

At individual scale, shoot growth correlated strongly with root growth (Fig. 1 and Tab. III). Relative irradiance had a strong positive impact on beech shoot and root biomass, and growth increment (Tab. III). The Vast 3 competition index correlated strongly with the biomass of beech shoot and roots (Fig. 2). Pinus sylvestris root biomass had a depletive effect on shoot and root development of Fagus, unlike herbaceous fineroot biomass (Tab. III). Since pine fine-root biomass accounted for the vast majority of stand root biomass, the total fine-root biomass of both competitors correlated significantly with beech growth. 

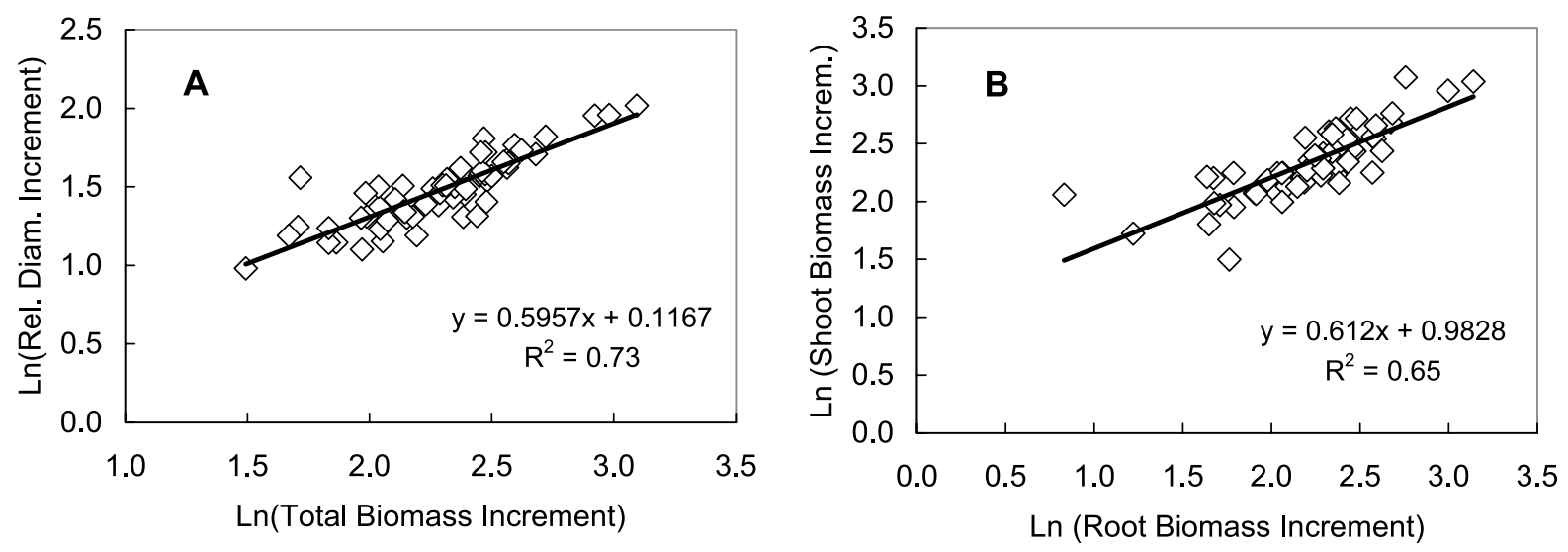

Figure 1. Relative stem diameter increment for beech seedlings versus total biomass increment after two years of experiment (A). Root- versus shoot biomass increment after two years of experiment (B). All data are ln-transformed.
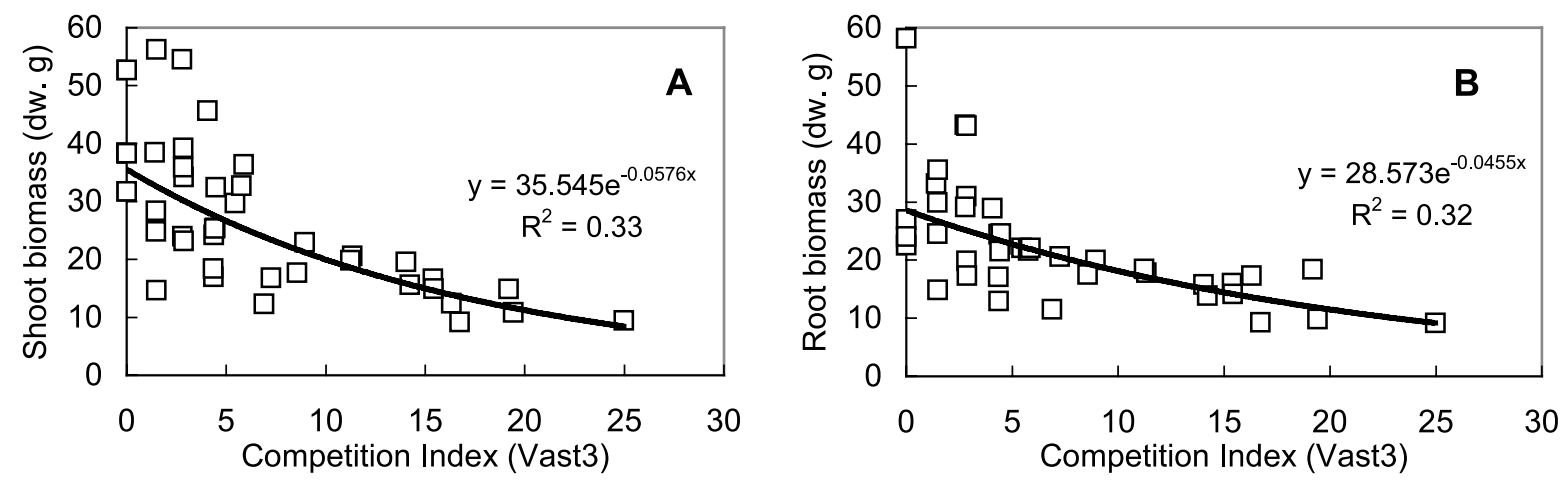

Figure 2. Shoot biomass increment versus the Vast 3 competition index (A). Root biomass increment versus the Vast 3 competition index (B). The Vast 3 competition index is the sum of vertical angles between the top of a seedling and the top of surrounding pines within a 3-m competition radius (explanations in the text).

Table III. Correlation matrix for seedling biomass two years after plantation and other measured variables. The table displays the $r$ Pearson correlation coefficients between pairs. Correlation significant at $P<0.001$ are shown in bold, $P<0.01$ in bold and italic, and $P<0.05$ in italic. Other values are not statistically significant $(P>0.05)$. Variables are total seedling biomass (TOB), shoot biomass (SHB); root biomass (ROB), relative stem diameter increment (SDI), relative irradiance (RIR), total herbaceous root biomass (RHT), total Scots pine root biomass (RPT), stand root biomass including pine and herbs (RCT), herbaceous aerial biomass (HAB), and the VAST3 competition index (VAS).

\begin{tabular}{lcccccccccc}
\hline Variables & TOB & SHB & ROB & SDI & RIR & RHT & RPT & RCT & HAB & VAS \\
\hline TOB & - & $\mathbf{0 . 9 7}$ & $\mathbf{0 . 9 5}$ & $\mathbf{0 . 7 3}$ & $\mathbf{0 . 5 9}$ & 0.07 & $-\mathbf{0 . 3 6}$ & -0.28 & 0.15 & $\mathbf{- 0 . 5 7}$ \\
SHB & - & - & $\mathbf{0 . 8 5}$ & $\mathbf{0 . 6 8}$ & $\mathbf{0 . 5 1}$ & 0.08 & $\mathbf{- 0 . 3 4}$ & -0.25 & 0.16 & $\mathbf{- 0 . 5 9}$ \\
ROB & - & - & - & $\mathbf{0 . 7 4}$ & $\mathbf{0 . 6 2}$ & 0.04 & $-\mathbf{0 . 3 7}$ & -0.31 & 0.14 & $\mathbf{- 0 . 5 6}$ \\
SDI & - & - & - & - & $\mathbf{0 . 7 4}$ & -0.08 & $-\mathbf{0 . 4 0}$ & -0.30 & 0.00 & $\mathbf{- 0 . 5 7}$ \\
RIR & - & - & - & - & - & -0.15 & $-\mathbf{0 . 5 7}$ & $\mathbf{- 0 . 4 6}$ & 0.04 & $\mathbf{- 0 . 6 0}$ \\
RHT & - & - & - & - & - & - & 0.00 & 0.07 & $\mathbf{0 . 5 5}$ & -0.23 \\
RPT & - & - & - & - & - & - & - & $\mathbf{0 . 9 0}$ & 0.00 & $\mathbf{0 . 3 8}$ \\
RCT & - & - & - & - & - & - & - & - & -0.02 & 0.24 \\
HAB & - & - & - & - & - & - & - & - & - & 0.31 \\
VAS & - & - & - & - & - & - & - & - & - \\
\hline
\end{tabular}


Table IV. Relative biomass allocation within plant compartments after the second growth season.

\begin{tabular}{|c|c|c|c|c|c|}
\hline Variable abbreviation & LL & $\mathrm{ML}-\mathrm{V}$ & $\mathrm{ML}+\mathrm{V}$ & HL & $\mathrm{FL}-\mathrm{V}$ \\
\hline $\operatorname{LWR}\left(\mathrm{g}^{-1} \mathrm{~g}^{-1}\right)$ & $0.08 a b$ & $0.09 a b$ & $0.10 b$ & $0.10 b$ & $0.07 a$ \\
\hline BWR $\left(\mathrm{g}^{-1} \mathrm{~g}^{-1}\right)$ & $0.13 a$ & $0.14 a$ & $0.13 a$ & $0.13 a$ & $0.12 a$ \\
\hline $\operatorname{SWR}\left(\mathrm{g}^{-1} \mathrm{~g}^{-1}\right)$ & $0.30 a$ & $0.32 a b$ & $0.32 a b$ & $0.31 a$ & $0.33 a b$ \\
\hline $\operatorname{TWR}\left(\mathrm{g}^{-1} \mathrm{~g}^{-1}\right)$ & $0.38 b$ & $0.32 a b$ & $0.29 a$ & $0.29 a$ & $0.29 a$ \\
\hline cRWR $\left(\mathrm{g}^{-1} \mathrm{~g}^{-1}\right)$ & $0.04 a b$ & $0.05 a b c$ & $0.09 c$ & $0.08 b c$ & $0.09 c$ \\
\hline fRWR $\left(g^{-1} g^{-1}\right)$ & $0.08 a$ & $0.09 a b$ & $0.08 a$ & $0.10 b$ & $0.10 b$ \\
\hline $\operatorname{RWR}\left(\mathrm{g}^{-1} \mathrm{~g}^{-1}\right)$ & $0.50 b$ & $0.45 a$ & $0.45 a$ & $0.47 a b$ & $0.48 b$ \\
\hline Shoot-root ratio & $1.03 a$ & $1.23 a$ & $1.23 a$ & $1.18 a$ & $1.12 a$ \\
\hline
\end{tabular}

Abbreviations are: leaf weight ratio (LWR), branch weight ratio (BWR), stem weight ratio (SWR), taproot weight ratio (TWR), coarse-roots weight ratio ( $>2 \mathrm{~mm}$, cRWR), fine-roots weight ratio $(<2 \mathrm{~mm}$, fRWR), total roots weight ratio (RWR). In e.g., leaf weight ratio (LWR) is the ratio of leaf biomass (g) to total plant biomass (g). LL: low irradiance; ML - V: medium irradiance and sparse herbaceous cover; HL: high irradiance; ML + V: medium irradiance and dense herbaceous cover; FL - V: full-light weeded.

A general linear model displayed a correct prediction of beech relative biomass increment $\left(R_{a d j}^{2}=0.40\right)$ with a strongly predominant effect of relative irradiance $(P<0.001)$, a non significant effect of pine root biomass $(P=0.6209)$, and a null effect of the herbaceous root biomass $(P=0.9921)$. Separate regression and covariance-nested analyses on shoot and root biomass resulted in similar results.

\subsection{Biomass allocation}

Relative biomass allocation within plants was computed in $\mathrm{g}$ per $\mathrm{g}$ of total seedling biomass to avoid size effects, and the possible effect of seedling mass was tested using a MANOVA. Biomass allocation and shoot-to-root ratios varied little among stands after two years (Tab. IV). Plant mass had no statistically significant effect on biomass allocation $(P>0.05)$ except for leaves $(F$-Ratio $=5.50 ; P=0.0236)$. Relative allocation to leaves tended to increase as plant mass decreased. Variations were slightly higher within the root system than within the shoot. Allocation to the taproot varied conversely with allocation to coarse roots $\left(r^{2}=-0.73, P<0.001\right)$, leaves $\left(r^{2}=-0.36\right.$, $P=0.0094)$, and fine-roots $\left(r^{2}=-0.28, P=0.0464\right)$. Allocation to the stem varied conversely with allocation to branches $\left(r^{2}=\right.$ $-0.30, P<0.0354)$. In stands with limited or nil herbaceous competition ( $\mathrm{LL}, \mathrm{ML}-\mathrm{V}$ and $\mathrm{FL}-\mathrm{V}$ ), increasing light enhanced allocation to coarse- and fine-roots at the expense of the taproot, while allocation within aerial parts varied insignificantly. For seedlings planted at full light without vegetation competition, more biomass was allocated proportionally to stem than to branches and leaves. At medium irradiance $(\mathrm{ML}-\mathrm{V}, \mathrm{ML}+\mathrm{V})$ allocation patterns were similar irrespective of vegetation competition. Regression analyses (data not shown) confirmed that: (i) relative irradiance did not correlate with allocation to stem and branches, which remained constant among stands; (ii) light enhanced coarse and fine roots $\left(R^{2}\right.$ adj was 0.68 and 0.52 , respectively) at the expense of the taproot; (iii) higher allocation to fine roots corresponded to higher beech growth both above- and belowground; and (iv) total root weight ratio was maximal at low- and full-light regime, and minimal at mediumlight regime.

\subsection{Above- and belowground morphological plasticity}

Beech fine-roots exhibited variable morphology among stands (Fig. 3), especially for SRL and average diameter $(P<$ $0.0001)$. The internode length varied less, but significantly $(P=$ 0.0297, data not shown). Beech seedlings had a low SRL and higher average diameter at shade (Fig. 3). At medium irradiance, the presence of an abundant herbaceous biomass (i.e., $\mathrm{ML}+\mathrm{V}$ versus $M L-V$ ) produced roots with a lower average diameter, a higher SRL and internode length. Conversely, Pinus sylvestris had thick and little-ramified fine roots with almost constant morphology among stands $(P>0.05$, Fig. 3$)$. Herbaceous fine roots were very thin and densely ramified, with considerable variations among stands. Overall, herbaceous fine roots tended to be finer and more ramified in stands with high irradiance and abundant graminae in comparison to forest dicots $(\mathrm{ML}+\mathrm{V}$, $\mathrm{HL}+\mathrm{V})$.

The SRL values for Fagus correlated slightly positively with the herbaceous fine-root biomass $\left(R_{a d j}^{2}=0.24, P<0.001\right)$ and negatively with the Vast 3 competition index $\left(R^{2} a d j=0.31, P<\right.$ $0.001)$. Average fine-root diameter correlated negatively with herbaceous fine-root biomass $\left(R_{a d j}^{2}=0.30, P<0.001\right)$. The abundance of Pinus fine roots had no significant effect on Fagus fine-root morphology.

Beech acclimation to shade at leaf level (i.e., high SLA) coincided with thicker and less-ramified roots (i.e., high average diameter, low SRL and low internode length). In the younger stands (LL, ML - V and HL) shading clearly resulted in an increase in SLA, paralleled by a decrease in SRL (Fig. 4A). The full-light and weeded plots had a very low SLA and a high SRL. Both stands at medium irradiance had similar SLA, while the dense herbaceous cover $(\mathrm{ML}+\mathrm{V})$ entailed an increase in SRL in comparison to that existing under the sparse herbaceous cover $(\mathrm{ML}-\mathrm{V})$. The fine-roots-to-leaf-mass ratio was similar among stands. It varied insignificantly with the relative irradiance $(P>0.05)$, and the fine-root abundance of pine or herbaceous ( $P>0.05$; Fig. 4B). Low SLA and high SRL values correlated positively with beech relative diameter increment (Fig. 5; $P<0.001$ ). 

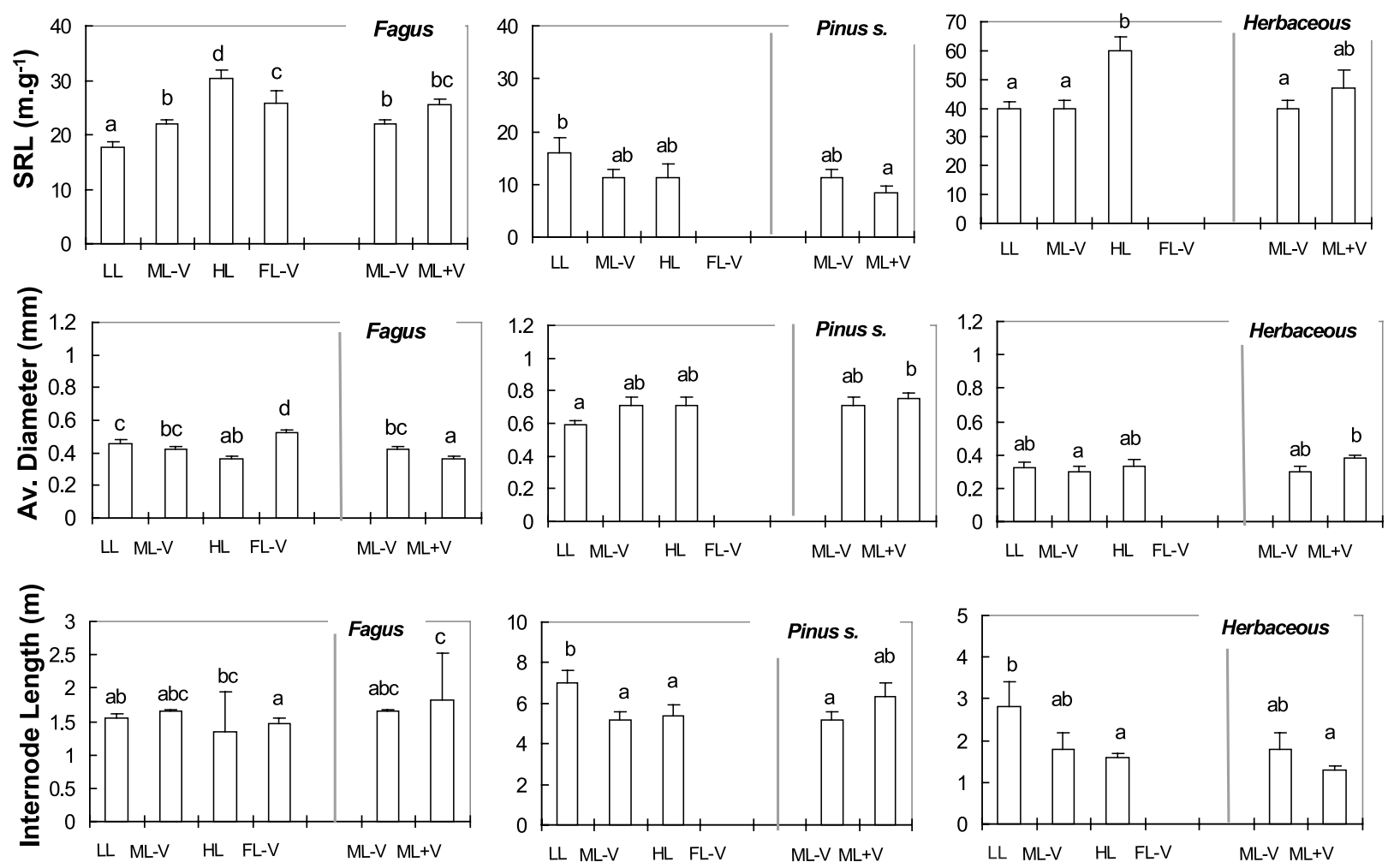

Figure 3. Variation in specific root length (SRL, $\mathrm{m}^{-1} \mathrm{~g}^{-1}$ ), average fine-root diameter (mm) and mean internode length (mm) for Fagus sylvatica seedlings, Pinus sylvestris and herbaceous species among stands. LL: low irradiance; ML - V: medium irradiance and sparse herbaceous cover; HL: high irradiance; ML + V: medium irradiance and dense herbaceous cover; FL - V: full-light weeded. Different letters in a graph indicate statistically significant differences (LSD procedure, $95 \%$ confidence interval).
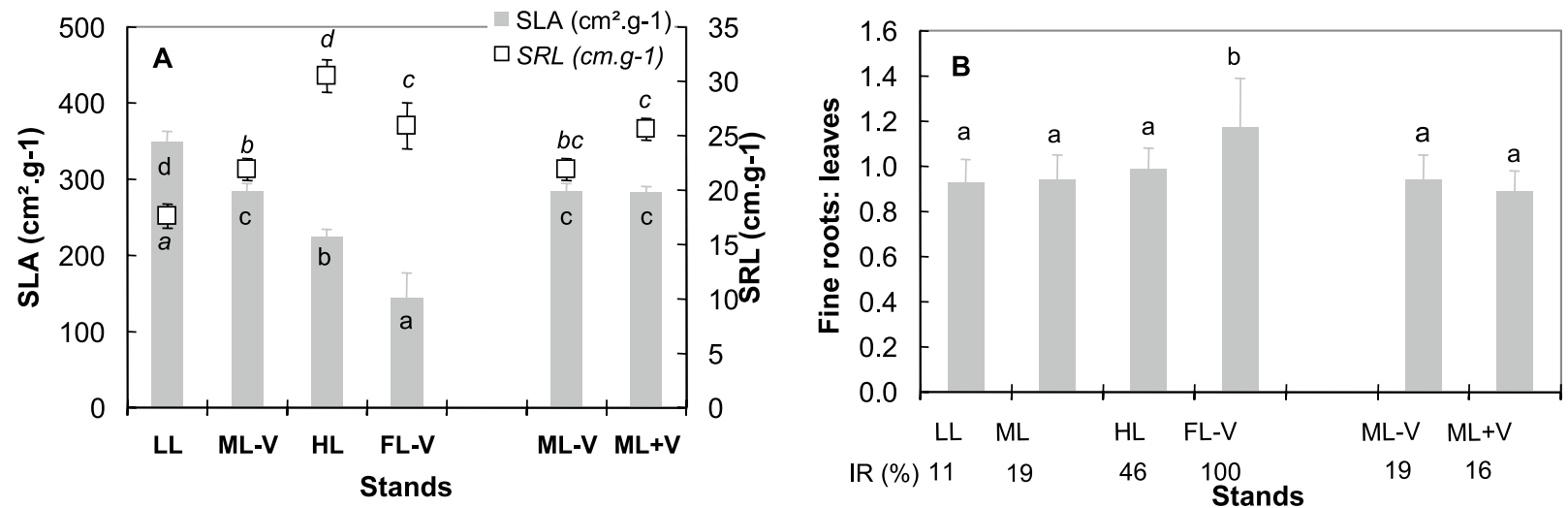

Figure 4. Variation among stands for specific leaf area (SLA) versus specific root length (SRL) (A); and fine-root to leaves biomass ratio (B). Vertical bars correspond to the standard error.

\section{DISCUSSION}

\subsection{Beech development in response to competitive stress}

Marked differences in the biomass of Fagus seedlings were found two years after plantation, our data being within the range reported in the literature at similar age $[6,11,43,49]$. This con- firms current indications that although Fagus tolerates shade and appreciates shelterwood, it responds favourably to canopy opening with enhanced growth $[8,11]$. Seedlings in full light in the weeded meadow had a three-fold higher biomass than those planted in shade under dense Pinus stands. Light regime is likely to be the main driving factor behind beech growth in our experiment since irradiance varied strongly among stands while edaphic constraints were similar. Shade reduced both 

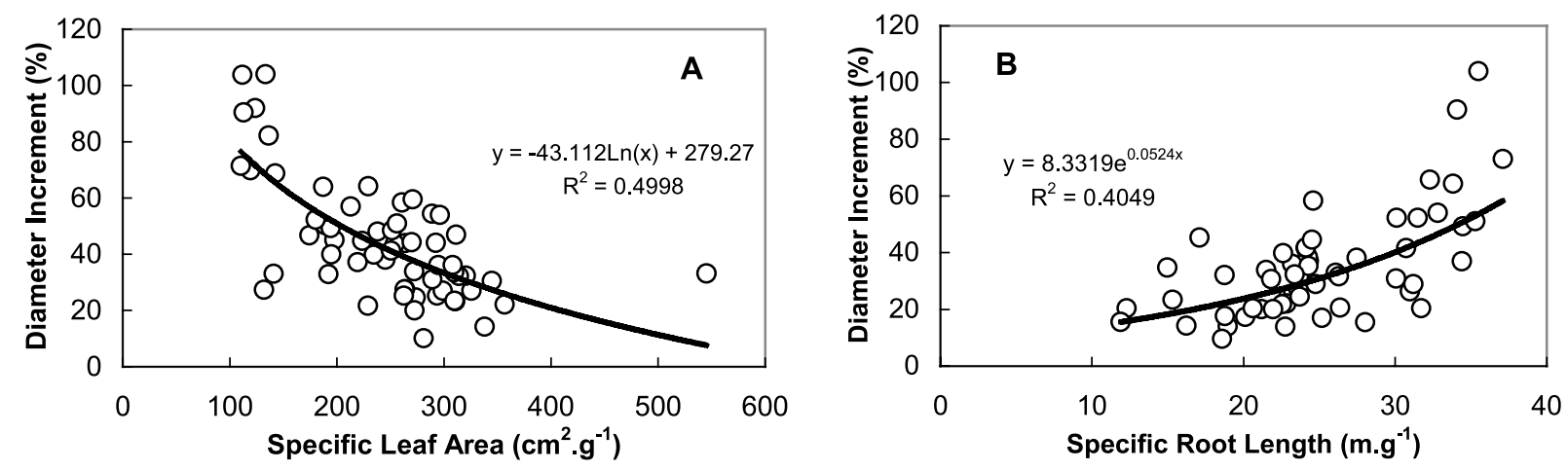

Figure 5. Relationships between relative diameter increment and specific leaf area (A) or specific root length (B) for Fagus seedlings. Relative diameter increment was computed as the ratio between the initial diameter (2000) and the final diameter (2002) in percentage.

shoot and root development, as reported elsewhere [36, 38, 49, 53]. Limited growth at low light (11\% relative irradiance) presumably results from reduced leaf area and photosynthetic activity [48], although Fagus is able to regenerate at a much lower irradiance of 3 to $5 \%$ [12, 30, 37]. Such limited growth is also hypothesized to maintain a positive carbon balance in reducing the loss by respiration [4], thus allowing late-successional species to survive for long periods at shade $[30,37]$.

Beech seedlings planted in unweeded plots in high or full light generally experience very low growth or high mortality $[8,9,25,34]$. Our results suggest that an ideal practice would be to install seedlings under full light in fully weeded parcels. However, such plantations entail cost- and time-consuming weeding that is unrealistic with respect to current forestry practices [15]. A compromise solution could be to favour beech installation in low-density stands similar to the ageing natural pine woodlands. Beech growth is likely to be rapid owing to a lateral shelterwood and an optimal incidental radiation of about $40 \%[8,25,36]$, despite a rather dense herbaceous cover.

Our experimental design suggested that weed competition is of secondary importance for beech development in comparison to competition from pines: (i) sparse herbaceous cover under shade obviously resulted in limited competition with Fagus (e.g. [31]); (ii) at medium irradiance, biomass increments were similar among stands with contrasted herbaceous covers; and (iii) stands with dense herbaceous cover and medium or high irradiance exhibit high beech growth. While the abundance of herbs above- or belowground had no impact on beech growth, pine fine roots had a moderate but unquestionably depletive effect at shoot- as at root-level. These results suggest the predominance of pine competition over herbaceous competition owing to disproportionate biomass amounts aboveand belowground. Our results contradict earlier studies indicating clear impact of competition from herbaceous roots (especially graminae) on the growth of beech seedlings [21, 34, 36]. First, this could result from high water- and nutrient-level of volcanic ash soils, which is likely to limit the impact of competition from herbaceous roots [8]. Second, Fagus roots demonstrated a clear ability to escape herbaceous competition by exploiting noncolonized soil volumes $[9,15,16]$. Our data give indications on the importance of competition for light versus competition for soil resources. The impact of pine was clearly higher aboveground (i.e. for light) than belowground, as reflected by the Vast 3 competition index.

\subsection{Allocation versus morphological plasticity}

The theory on global allocation for biomass partitioning in plants [45] assumes that shading results in higher relative biomass allocation to the stem, constant allocation to the foliage and lower allocation to the fine roots in comparison to high- or full-light $[29,49]$ conditions. As a consequence, the shoot-toroot ratio is expected to increase in shade for both shade-tolerant [38, 53] and shade-intolerant boreal tree species [31, 42]. Our results indicated a depletive impact of shade for all beech compartments (see [2,38]), a low impact of light regime on biomass allocation within plants on a constant mass basis, and insignificant variation in shoot-to-root ratio among stands (see [2]). However, both light and herbaceous competition enhanced allocation to fine and coarse roots at the expense of taproot, in agreement with earlier findings [7, 16, 35, 49].

Recent debates focused on the question whether abiotic stresses produce predominantly morphological adjustments or changes in allocation plasticity along life-cycle in higher plants $[4,22,24,44,46]$. Our findings support the hypothesis that, for a constant seedling mass, allocation to leaves, stems and roots varied little with light availability [28, 31, 35, 42] or herbaceous competition [28]. As a late-successional species, beech is especially expected to show a progressive shift in biomass allocation along life-cycle $[4,29]$. These results confirm that biomass allocation would be mostly ontogenic, thus variable along tree life [24, 49]. Likewise, the shoot-to-root ratio is likely to be highly integrative, and poorly indicative of environmental conditions [18].

A major finding is that morphological adjustments at leaf level and root level predominated over allocational adjustments in relation to irradiance and herbaceous competition (e.g. [1, $3,5,27])$. Fagus responded to changes in light environment by adjusting its leaf morphology, especially having higher SLA under shade (e.g. [5, 29, 37]). Spatial distribution of leaves within the crown also participate to reduce self-shading [39]. These strategies are hypothesized to maximize the light capture 
[14, 26, 30, 37, 39, 42, 51]. Such adjustments at leaf-level generally coincide with an increase in leaf area ratio, lateral crown expansion, and plasticity in the spatial arrangement of leaves $[22,47]$, which are typical features of shade-tolerant species [26, 37, 40, 49].

Morphological plasticity of roots in response to shade and herbaceous competition has been little investigated in the literature for Fagus [15, 16] and other tree species (e.g. [3]). Coarser roots under shade may result from direct effects of low light regime, i.e. low shoot growth corresponds to low root growth [13]. Conversely, fast-growing species exhibit large organs and rapid resource acquisition at shoot- and root-level [42]. Thin and ramified beech roots in the presence of herbaceous competition correspond to a foraging strategy to better exploit soil resources, and presumably to resist to resource depletion [3, 27, 37, 43]. Maximal root foraging occurred at high irradiance with maximal herbaceous competition. In contrast to the competitive Fagus [16, 43], the conservative Pinus sylvestris $[3,15,16]$ had an almost null adaptive strategy for improving its soil exploitation efficiency according to changes in light and belowground competition.

\subsection{Ecological implications}

High SRL and low SLA at high irradiance corresponded to high growth potential for Fagus, in accordance with the literature on many plant species [13, 14, 42, 52]. High SRL is hypothesized to allow beech to capture the limiting soil resources to maintain (or enhance) its growth [46], while low SLA is typical of sun leaves [39]. While early-successional and shade-intolerant species would demonstrate very rapid morphological adaptation [5, 37], competitive and shade-tolerant species such as Fagus should adapt more slowly. They are hypothesized to favour morphological adjustment rather than allocation adjustments to allow surviving and growing in shade [27, 40]. Fagus sylvatica holds an intermediate reaction to shading between highly-reactive species such as Betula pen$d u l a$ that show a strong acclimation in terms of biomass partitioning and morphological adjustment of leaves, and low-reactive species such as Quercus robur that react little aboveground but demonstrate enhanced root foraging [49]. Investigating to what extent leaves and fine roots may increase their physiological efficiency to maintain a balanced carbon-nutrient uptake within beech saplings would provide an interesting complement to this study (e.g. [4, 35, 48]).

Acknowledgments: We greatly acknowledge to our colleagues for their valuable help in the field and in the lab work (M. Bouchaud, R. Jouvie, F. Landré, A. Marquier), and to E. Garnier (CNRS-Cefe Montpellier) who provided very useful comments on our data. We greatly acknowledge the two anonymous reviewers for their essential help to improve the manuscript. This research was funded by the French Ministry for Land Management (contract \# No. 043/2000).

\section{REFERENCES}

[1] Aerts R., Boot R.G.A., van der Aart P.J.M., The relation between above- and belowground biomass allocation patterns and competitive ability, Oecologia 87 (1991) 551-559.
[2] Ammer C., Growth and biomass partitioning of Fagus sylvatica L. and Quercus robur L. seedlings in response to shading and small changes in the R/FR-ratio of radiation, Ann. For. Sci. 60 (2003) 163-171.

[3] Bauhus J., Messier C., Soil exploitation strategies of fine roots in different tree species of the southern Boreal forest of eastern Canada, Can. J. For. Res. 29 (1999) 260-273.

[4] Bazzaz F.A., Plants in changing environment. Linking physiological, population and community ecology, Cambridge Univ. Press, 1998.

[5] Beaudet M., Messier C., Growth and morphological responses of yellow birch, sugar maple, and beech seedlings growing under a natural light gradient, Can. J. For. Res. 28 (1998) 1007-1015.

[6] Büttner V., Leuschner C., Spatial and temporal patterns of root abundance in a mixed oak-beech forest, For. Ecol. Manage. 70 (1994) 11-21.

[7] Cao K.F., Ohkubo T., Allometry, root/shoot ratio and root architecture in understory saplings of deciduous dicotyledonous trees in central Japan, Ecol. Res. 13 (1998) 217-227.

[8] Coll L., Balandier P., Picon-Cochard C., Prévosto B., Curt T., Competition for water between beech seedlings and surrounding vegetation in different light and vegetation composition conditions, Ann. For. Sci. 60 (2003) 593-600.

[9] Coll L., Balandier P., Picon-Cochard C., Morphological and physiological response of beech (Fagus sylvatica) seedlings to grassinduced belowground competition, Tree Physiol. 24 (2004) 45-54.

[10] Collet C., Frochot H., Guehl J.M., Growth dynamics and water uptake of two forest grasses differing in their growth strategy and potentially competing for forest seedlings, Can. J. Bot. 74 (1996) 1555-1561.

[11] Collet C., Lanter O., Pardos M., Effects of canopy opening on height and diameter growth in naturally regenerated beech seedlings, Ann. For. Sci. 58 (2001) 127-134.

[12] Coomes D.A., Grubb P.J., Impacts of root competition in forests and woodlands: a theoretical framework and review of experiments, Ecol. Monogr. 70 (2000) 171-207.

[13] Comas L.H., Bouma T.J., Eissenstat M., Linking root traits to potential growth rate in six temperate tree species, Oecologia 132 (2002) 34-42.

[14] Cornelissen J.H.C., Castro Diez P., Hunt R., Seedling growth, allocation and leaf attributes in a wide range of woody plant species and types, J. Ecol. 84 (1996) 755-765.

[15] Curt T., Prévosto B., Root biomass and rooting profile of naturally regenerated beech in mid-elevation Scots pine woodlands, Plant Ecol. 167 (2003) 269-282.

[16] Curt T., Prévosto B., Rooting strategy of naturally regenerated beech in Silver birch and Scots pine woodlands, Plant Soil, Special Issue 255: 265-279 (2003) 265-279.

[17] Ellenberg H., Vegetation Ecology of Central Europe, 4th ed., Cambridge University Press, Cambridge, UK, 1988.

[18] Enquist B.J., Niklas K.J., Global allocation rules for patterns of biomass partitioning in seed plants, Science 295 (2002) 1517-1520.

[19] Finér L., Messier C., DeGrandpré L., Fine-root dynamics in mixed Boreal conifer-broadleaf forest communities at different successional stages after fire, Can. J. For. Res. 27 (1997) 304-314.

[20] Fitter A.L., An architectural approach to the comparative ecology of plant root systems, New Phytol. 106 (1988) 61-77.

[21] Fotelli M.N., Gessler A., Peuke A.D., Rennenberg H., Drought affects the competitive interactions between Fagus sylvatica seedlings and an early successional species, Rubus fruticosus: responses of growth, water status and delta C-13 composition, New Phytol. 151 (2001) 427-435.

[22] Garnier E., Resource capture, biomass allocation and growth in herbaceous plants, Trends Ecol. Evol. 6 (1991) 126-131.

[23] Garnier E., Shipley B., Roumet C., Laurent G., A standardized protocol for the determination of specific leaf area and leaf dry matter content, Funct. Ecol. 15 (2001) 688-695.

[24] Gedroc J.J., McConnaughay K.D.M., Coleman J.S., Plasticity in root/shoot partitioning: optimal, ontogenic, or both? Funct. Ecol. 10 (1996) 44-50. 
[25] Gemmel P., Nilsson U., Welander T., Development of oak and beech seedlings planted under varying shelterwood densities and with different site preparation methods in southern Sweden, New For. 12 (1996) 141-161.

[26] Givnish T.J., Leaf and canopy adaptations in tropical forests, in: Medina E., Mooney H.A., Vasquez-Yanes C. (Eds.), Physiological ecology of plants of wet tropics, W. Junk Publ., The Hague, 1984, pp. 51-84.

[27] Grime J.P., Hodgson J.G., Hunt R., Comparative plant ecology: a functional approach to common British species, Unwin Hyman, London, 1988.

[28] Kaelke C.M., Kruger E.L., Reich P.B., Trade-offs in seedling survival, growth, and physiology among hardwood species of contrasting successional status along a light-availability gradient, Can. J. For. Res. 31 (2001) 1602-1616.

[29] Kitajima K., Relative importance of photosynthetic traits and allocation patterns as correlates of seedlings shade tolerance of 13 tropical trees, Oecologia 98 (1994) 419-428.

[30] Kobe R.K.S., Pacala S.W., Silander J.A., Canham C.D., Juvenile tree survivorship as a component of shade tolerance, Ecol. Appl. 5 (1996) 517-532.

[31] Kolb T.E., Steiner K.C., Growth and biomass partitioning of northern red oak and yellow-poplar seedlings: effects of shading and grass root competition, For. Sci. 36 (1990) 34-44.

[32] Kunstler G., Curt T., Lepart J., Spatial pattern of beech and oak seedlings in naturally regenerated Pinus woodlands, Eur. J. For. Res. 1 (2005) 1-13.

[33] Küppers M., Canopy gaps: competitive light interception and economic space filling: A matter of whole-plant allocation, in: Caldwell M.M., Pearcy R.W. (Eds.), Exploitation of environmental heterogeneity by plants: Ecophysiological processes above- and belowground, Acad. Press, San Diego, California, 1994, pp. 111-144.

[34] Löf M., Establishment and growth in seedlings of Fagus sylvatica and Quercus robur: influence of interference from herbaceous vegetation, Can. J. For. Res. 30 (2000) 855-864.

[35] Machado J.L., Walters M.B., Reich P.B., Below-ground resources limit seedling growth in forest understories but does not alter biomass distribution, Ann. For. Sci. 60 (2003) 1-12.

[36] Madsen P., Effects of soil water content, fertilization, light, weed competition and seedbed type on natural regeneration of beech (Fagus sylvatica), For. Ecol. Manage. 72 (1995) 251-264.

[37] Messier C., Nikinmaa E., Effects of light availability and sapling size on the growth, biomass allocation, and crown morphology of understory sugar maple, yellow birch, and beech, Ecoscience 7 (2000) 345-356.

[38] Minotta G., Pinzauti S., Effects of light and soil fertility on growth, leaf chlorophyll content and nutrient use efficiency of beech (Fagus sylvatica L.) seedlings, For. Ecol. Manage. 86 (1996) 61-71.
[39] Planchais I., Sinoquet H., Foliage determinants of light interception in sunny and shaded branches of Fagus sylvatica (L.), Agric. For. Meteorol. 89 (1998) 241-253.

[40] Pregitzer K.S., DeForest J.L., Burton A.J., Allen M.F., Ruess R.W., Hendrick R.L., Fine root architecture of nine North American trees, Ecol. Monogr. 72 (2002) 293-309.

[41] Prévosto B., Curt T., Gueugnot J., Coquillard P., Modelling midelevation Scots pine growth on a volcanic substrate, For. Ecol. Manage. 131 (2000) 223-237.

[42] Reich P.B., Tjoelker M.G., Walters M.B., Vanderklein D.W., Bushena C., Close association of RGR, leaf and root morphology, seed mass and shade tolerance in seedlings of nine boreal tree species grown in high and low light, Funct. Ecol. 12 (1998) 327-338.

[43] Rust S., Savill P.S., The root system of Fraxinus excelsior and Fagus sylvatica and their competitive relationships, Forestry 5 (2000) 499-508.

[44] Sack L., Grubb P.J., The combined impacts of deep shade and drought on the growth and biomass allocation of shade-tolerant woody seedlings, Oecologia 131 (2002) 175-185.

[45] Sack L., Maranon T., Grubb P.J., Global allocation rules for patterns of biomass partitioning, Science 296 (2002) 5575

[46] Shipley B., Meziane D., The balanced-growth hypothesis and the allometry of leaf and root biomass allocation, Funct. Ecol. 16 (2002) 326-331.

[47] Thornley J.H.M., Root:shoot interactions, in: Jennings D.M. (Ed.), Integration of Activity in the Higher Plants, Cambridge University Press, London, 1977, pp. 367-387.

[48] Valladares F., Chico J.M., Aranda I., Balaguer L., Dizengremel P., Manrique E., Dreyer E., The greater seedling high-light tolerance of Quercus robur over Fagus sylvatica is linked to a greater physiological plasticity, Trees 16 (2002) 395-403.

[49] Van Hees A.F.M., Clerkx A.P.P.M., Shading and root-shoot relations in saplings of silver birch, pedunculate oak and beech, For. Ecol. Manage. 176 (2003) 439-448.

[50] Vogt K.A., Vogt D.J., Palmiotto P.A., Boon P., O'Hara J., Asbjornsen H., Review of root dynamics in forest ecosystems grouped by climate, climatic forest type and species, Plant Soil 187 (1996) 159219

[51] Walters M.B., Reich P.B., Seed size, nitrogen supply, and growth rate affect tree seedling survival in deep shade, Ecology 81 (2000) $1887-1901$.

[52] Welander N.T., Ottosson B., The influence of shading on growth and morphology in seedlings of Quercus robur L. and Fagus sylvatica L., For. Ecol. Manage. 107 (1998) 117-126.

[53] Wright I.J., Westoby M., Cross-species relationships between seedling relative growth rate, nitrogen productivity and root vs. leaf function in 28 Australian woody species, Funct. Ecol. 14 (2000) 97-107. 